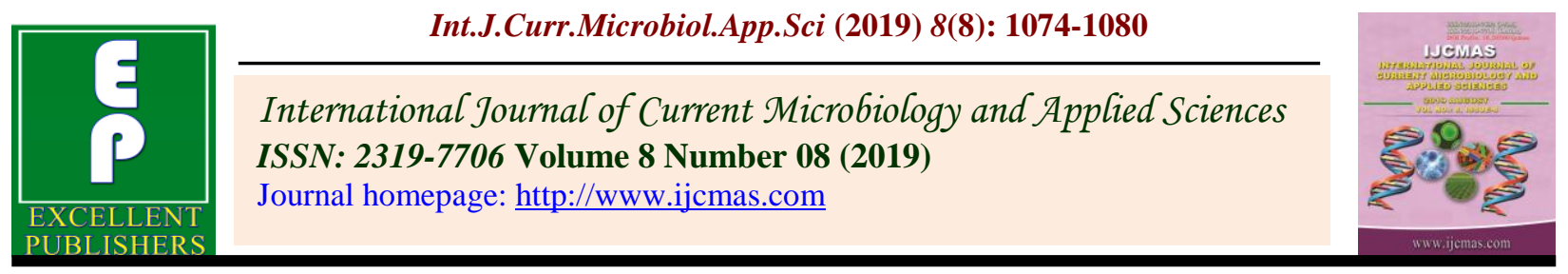

Original Research Article

https://doi.org/10.20546/ijcmas.2019.808.125

\title{
Detection of E. coli from Sheep and Goat Faecal Samples and Identification by Conventional and Molecular Assay
}

\author{
K. Kumar, N. S. Sharma, Paviter Kaur* and A.K. Arora
}

Department of Veterinary Microbiology, Guru Angad Dev Veterinary and Animal Sciences University, Ludhiana-141004, India

*Corresponding author

\begin{tabular}{|l|}
\hline Ke y w or d s \\
E. coli, Sheep, \\
Goats, Biochemical \\
test, PCR
\end{tabular}

\section{A B S T R A C T}

E. coli is a Gram negative bacteria belonging to enterobacteriacea family. They are commonly found in the intestine of animals and humans. Most $E$. coli are harmless but some can cause infection. In our study, we isolated E.coli from 100 (50 from sheep and 50 from goats) faecal samples of diarrhoeic as well as healthy sheep. Isolation was done on BHI, MLA and EMB agar. The isolated bacteria suspected for $E$. coli were subjected to biochemical tests viz catalase, oxidase and IMViC. The isolates confirmed by biochemical tests were further confirmed by genus specific PCR. Out of 100 samples, 40 samples were positive for presence of E. coli. On BHI creamy mucoid colonies were formed, while as on MLA lactose fermenting pink colonies were formed. On EMB, colonies with characteristic metallic sheen were formed. All the isolates were catalase positive, oxidase negative and gave a characteristic pattern in IMViC test i.e. indole positive, methyl red positive, Voges Prausker and citrate negative. The 40 isolates were subjected to genus specific PCR out of which 26 isolates were confirmed as E. coli.

\section{Introduction}

E. coli is a Gram-negative, facultative anaerobe and nonsporulating bacterium. Cells are typically rod-shaped, and are about $2.0 \mu \mathrm{m}$ long and $0.25-1.0 \mu \mathrm{m}$ in diameter, with a cell volume of $0.6-0.7 \mu^{3}$ (Loo et al., 2014). Escherichia coli is a bacterial commensal of the intestinal microflora of a variety of animals, including humans. Not all
E. coli strains are harmless, as some are able to cause diseases in humans as well as in mammals and birds (Dho-Moulin et al., 1999). Pathogenic E. coli strains fall into two categories: those that cause intestinal pathologies and those that cause extra intestinal pathologies. Intestinal pathologies mostly consist of more or less severe diarrhoea caused by different $E$. coli pathotypes such as enterotoxinogenic, 
enteropathogenic or enterohaemorragic E. coli (ETEC, EPEC and EHEC, respectively), potentially evolving into a haemolytic uremic syndrome (HUS) in the case of EHEC infections (Kaper et al., 2005). The emergence of verotoxigenic $E$. coli (VTEC) as human pathogens, contamination of food of animal origin has been a major public health concern. Infected cattle and sheep are considered the main reservoir of VTEC, with spread in human and animals associated with the consumption of contaminated beef and beef products (Griffin and Tauxe 1991) or direct contact with animals and animal faeces on the farm Around 29 strains of E.coli have been reported from sheep and 16 stains from goat (Vicente et al., 2005). Animal and human commensal microbiota, especially intestinal microbiota, are subjected to numerous antimicrobial pressures due to farming practices and veterinary and human medicines. They have been suggested to play a major role in disseminating bacterial resistance (Kang et al., 2005). Keeping these facts in view we isolated E. coli from faecal samples of sheep and goats which were confirmed by biochemical test and genus specific PCR.

\section{Materials and Methods}

\section{Collection of samples and isolation of bacteria}

The current study was ethically approved by Institutional Animal Ethics Committee. A total of 100 faecal samples were collected from healthy as well as diarrhoeic sheep and goats, from farms in and around Ludhiana, Punjab. These samples were aseptically collected in sample collection container and immediately kept in ice box and transferred to the laboratory. The samples were then subjected to bacterial isolation, followed by identification of isolates and PCR. The faecal samples brought to the laboratory were inoculated on BHI, MLA, EMB agar
(Himedia). The inoculated plates were incubated at $37^{\circ} \mathrm{C}$ for $16-24$ hours. The suspected colonies after incubation were subjected to Gram's staining for identification and subjected to various biochemical tests for confirmation.

\section{Identification of isolates by biochemical tests}

The isolates were confirmed by various biochemical tests like oxidase, catalase and IMViC test. IMViC test was performed using IMViC test kit (Himedia) as per the manufacturers' recommendations. Pick up the E. coli colonies from the media (EMB) by inoculation loop, then streak on to wells and incubated $37^{\circ} \mathrm{C}$ for $18-24 \mathrm{hrs}$. For Indole test, after inoculation and incubation add 2-3 drops of Kovac's reagent in first well. If pink colour is obtained, then it is positive reaction. For MR test, add 1-2 drops of Methyl Red reagent in second well. If red colour obtained, the test is positive. For VP test, add 2-3 drops of Baritt reagent $A$ and 1 drop of Baritt reagent $B$ in third well. Pinkish red colour obtained 5-10 minutes indicates a positive test. For citrate test if colour change to blue then it is positive for citrate utilization.

\section{Confirmation by genus specific PCR Extraction of genomic DNA}

The DNA of E. coli isolates was extracted using NucleoSpin ${ }^{\circledR}$ Microbial DNA kit (Macherey Nagel) as per manufacturer's instructions. Bacterial cells grown in a broth were harvested by centrifugation in a microcentrifuge tube and supernatant was discarded. Then approximately $40 \mathrm{mg}$ of wet weight microbial cell culture pellet was taken and $100 \mu \mathrm{L}$ Elution Buffer BE was added and cells were resuspended. Cell suspension was transferred into the NucleoSpin ${ }^{\circledR}$ Bead Tube Type B and $40 \mu \mathrm{L}$ Buffer MG was added. Then, $10 \mu \mathrm{L}$ Liquid Proteinase $\mathrm{K}$ was added 
and mixed by vortexing for $4 \mathrm{~min}$. NucleoSpin ${ }^{\circledR}$ Bead Tubes were centrifuged at $11,000 \mathrm{x} \mathrm{g}$ for $30 \mathrm{~s}$. After this $600 \mu \mathrm{L}$ Buffer MG was added, mixed and vortexed for $3 \mathrm{~s}$. The tubes were centrifuged again for $30 \mathrm{~s}$ at $11,000 \mathrm{x}$ g. Supernatant was Transferred $(500-600 \mu \mathrm{L})$ onto the NucleoSpin ${ }^{\circledR}$ Microbial DNA Column, placed in a $2 \mathrm{~mL}$ Collection Tube. Again centrifugation was done for $30 \mathrm{~s}$ at $11,000 \mathrm{x} \mathrm{g}$. Columns were transferred into a fresh Collection Tube. $500 \mu \mathrm{L}$ Buffer BW was added. Again the centrifugation was done for $30 \mathrm{~s}$ at $11,000 \mathrm{xg}$. After Discarding the flow through the columns were placed back into the Collection Tube and $500 \mu \mathrm{L}$ Buffer B5 was added to the column and centrifuged for $30 \mathrm{~s}$ at $11,000 \mathrm{x}$. In order to Dry silica membrane the column was centrifuged for $30 \mathrm{~s}$ at $11,000 \mathrm{x}$. Then highly pure DNA was eluted by Placing the NucleoSpin ${ }^{\circledR}$ Microbial DNA Column into a $1.5 \mathrm{~mL}$ nuclease-free tube and $100 \mu \mathrm{L}$ Elution Buffer BE was added to the column. The column was incubated was at room temperature for $1 \mathrm{~min}$ then centrifuged at $11,000 \mathrm{x} \mathrm{g}$ for $30 \mathrm{~s}$. Purity and concentration of the extracted genomic DNA was estimated by using a Nanodrop (Thermo Scientific, USA).

\section{Extraction of genomic DNA by hot-cold lysis method}

Four to five colonies of the suspected $E$. coli isolates were taken into $1 \mathrm{ml}$ of sterile distilled water/ normal saline in $1.5 \mathrm{ml}$ microcentrifugation tube (MCT) to make a homogeneous suspension. MCT containing the suspension was then placed into a waterbath preheated to $100^{\circ} \mathrm{C}$. The suspension was boiled for 10 minutes at this temperature. MCT containing the suspension was then immediately transferred to ice kept at $20^{\circ} \mathrm{C}$.Centrifugation was done and supernatant was collected. Extracted DNA was then stored at $-20^{\circ} \mathrm{C}$ for further use.

\section{Polymerase Chain Reaction (PCR)}

PCR was done by using already published $E$. coli genus specific primers (Riffin et al., 2001). A Reaction mixture of $25 \mu \mathrm{L}$ was prepared consisting of $12.5 \mu \mathrm{L}$ mastermix (Promega), forward primer $1 \mu \mathrm{L}(20 \mathrm{pmol})$, reverse primer $1 \mu \mathrm{L}(20 \mathrm{pmol}), 3 \mu \mathrm{L}$ of template DNA, $7.5 \mu \mathrm{L}$ nuclease free water. PCR cycling conditions consisted of an initial denaturation at $94^{\circ} \mathrm{C}$ for 5 minutes followed 30 cycles each of denaturation at $94^{\circ} \mathrm{C}$ for 45 seconds, annealing at $55^{\circ} \mathrm{C}$ for 45 seconds and extension at $72^{\circ} \mathrm{C}$ for 1 minute.

This was followed by a final extension at $72^{\circ} \mathrm{C}$ for 10 minutes. The amplified products were analysed by electrophoresis at $80 \mathrm{~V}$ for $1 \mathrm{hr}$ in $1.0 \%$ agarose gel in $1 \mathrm{x}$ TBE buffer containing ethidium bromide and visualized under Alpha imager gel documentation system (Alpha innotech) and photographed.

\section{Results and Discussion}

\section{Isolation and identification of $E$. coli spp.}

A total of 100 samples were processed for isolation of E. coli. Out of 100 samples 40 samples were positive for presence of E. coli. On BHI colonies are spherical, creamy mucoid in nature (Fig. 1), on MLA lactose fermented pink colour colonies were present (Fig. 2) and on EMB colonies shows metallic sheen (Fig. 3). Pink colour coccobacilli bacterial were present while doing Grams staining (Fig. 4). During confirmation by biochemical tests, E.coli were found to be catalase positive (Fig. 5), oxidase negative and in IMViC test indole, methyl red positive and Voges Proskauer and citrate negative (Fig. 6). The colony characteristics of the isolated $E$. coli in different media resemble the colony characteristics of E. coli as stated by Ali et al., (1998). They reported that the faecal isolates showed various colony characteristics and 
biochemical reactions in different production of both acid and gas. Results of bacteriological agar media. All the E. coli isolates were found to be positive in catalase, methyl-red positive and indole but negative to VP test which supports the findings of Beutin et al., (1993). In the present study the isolated E. coli organism fermented dextrose, maltose, lactose, sucrose and manitol with the MR, Indole test of the E. coli isolates were positive as reported by Buxton and Fraser 1977. In Gram's staining, the morphology of the isolated bacteria exhibited pink, small rod shape, Gram negative bacilli which were supported by several authors (Buxton and Fraser 1977; Freeman 1985).

Fig.1 E. coli on BHI shows cream colour, mucus type colony

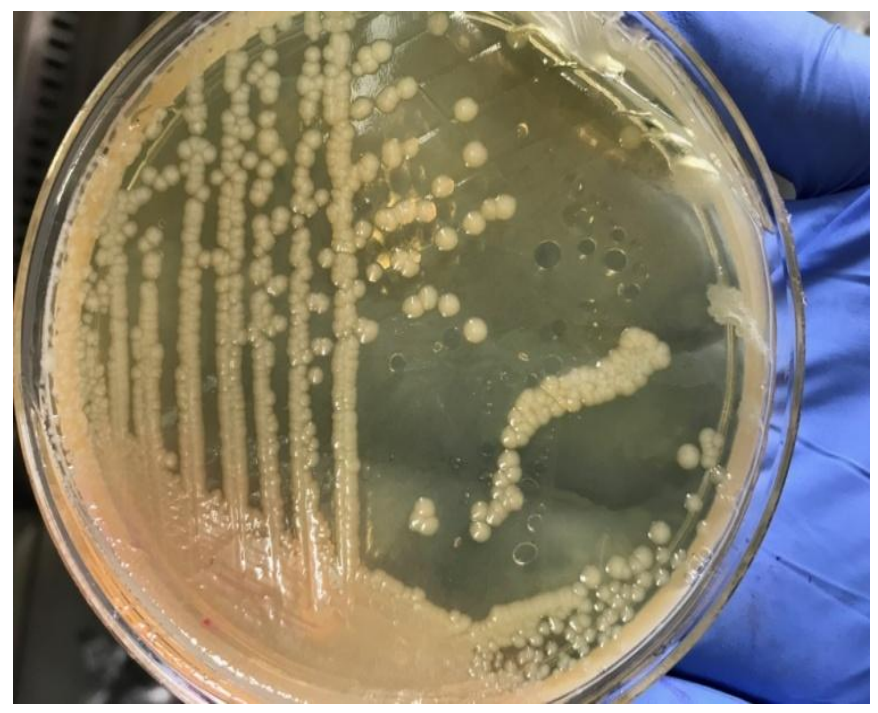

Fig.2 E. coli on MLA showing pink coloured colonies

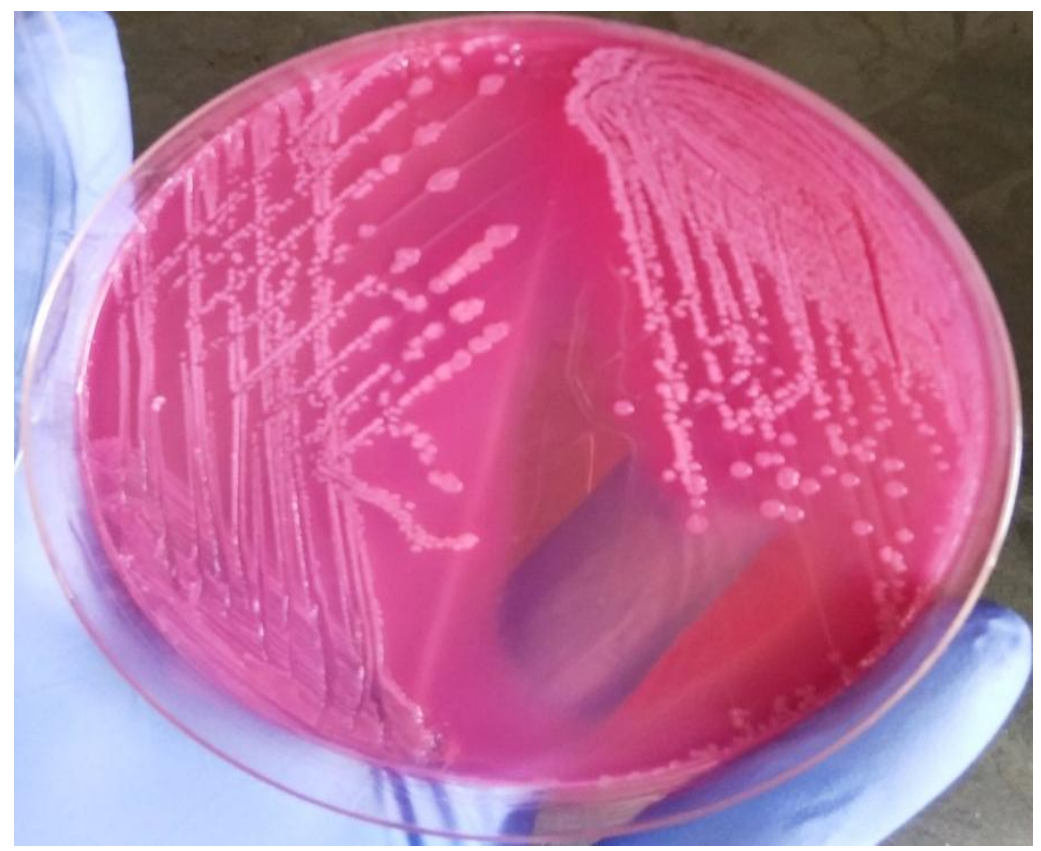


Fig.3 E. coli on EMB showing metallic sheen

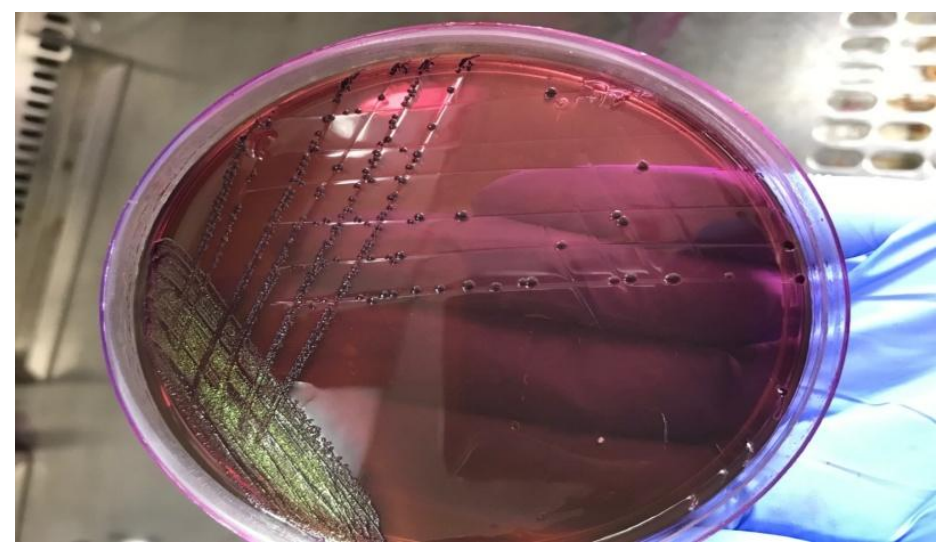

Fig.4 E. coli Gram negative bacteria shows pink colour bacilli

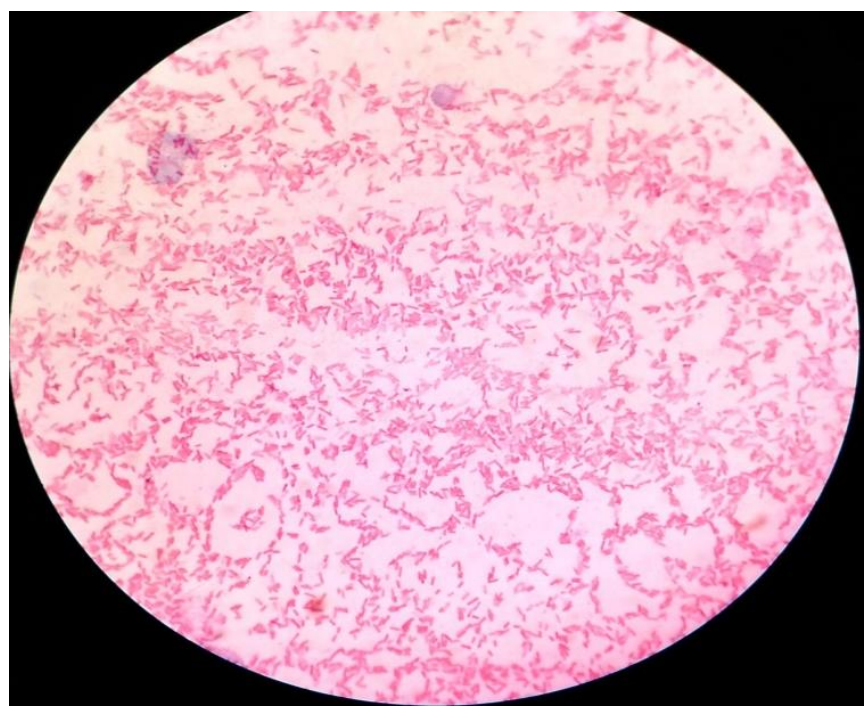

Fig.5 E. coli is catalase positive

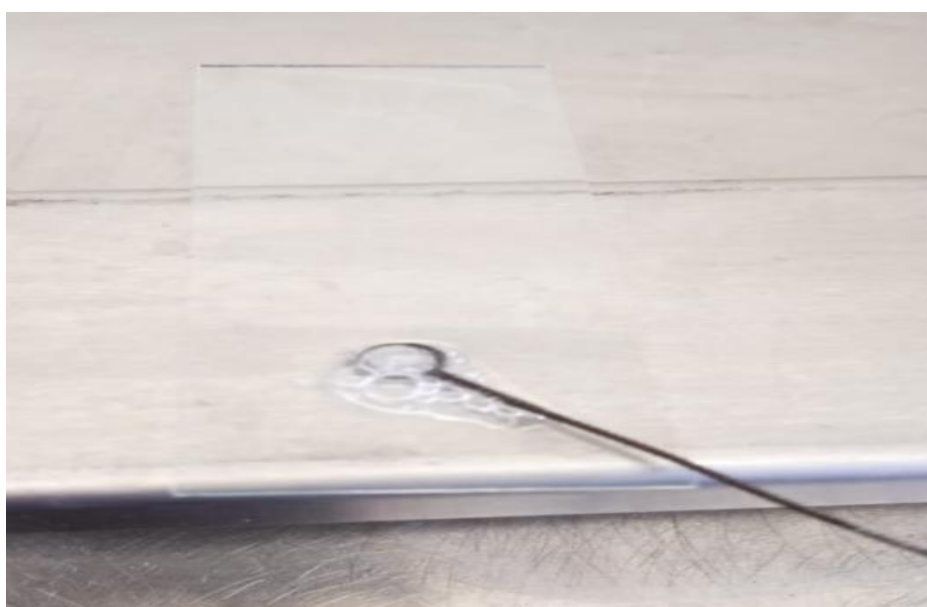


Fig.6 Gel electrophoresis of PCR amplified fragment from E.coli isolates by using genus specific primer pair ( $\mathrm{L} 1=100 \mathrm{bp}$ DNA ladder, $\mathrm{L} 2,3,4$, = positive samples $\mathrm{L}=5$ positive control and $\mathrm{L}=6$ negative control)

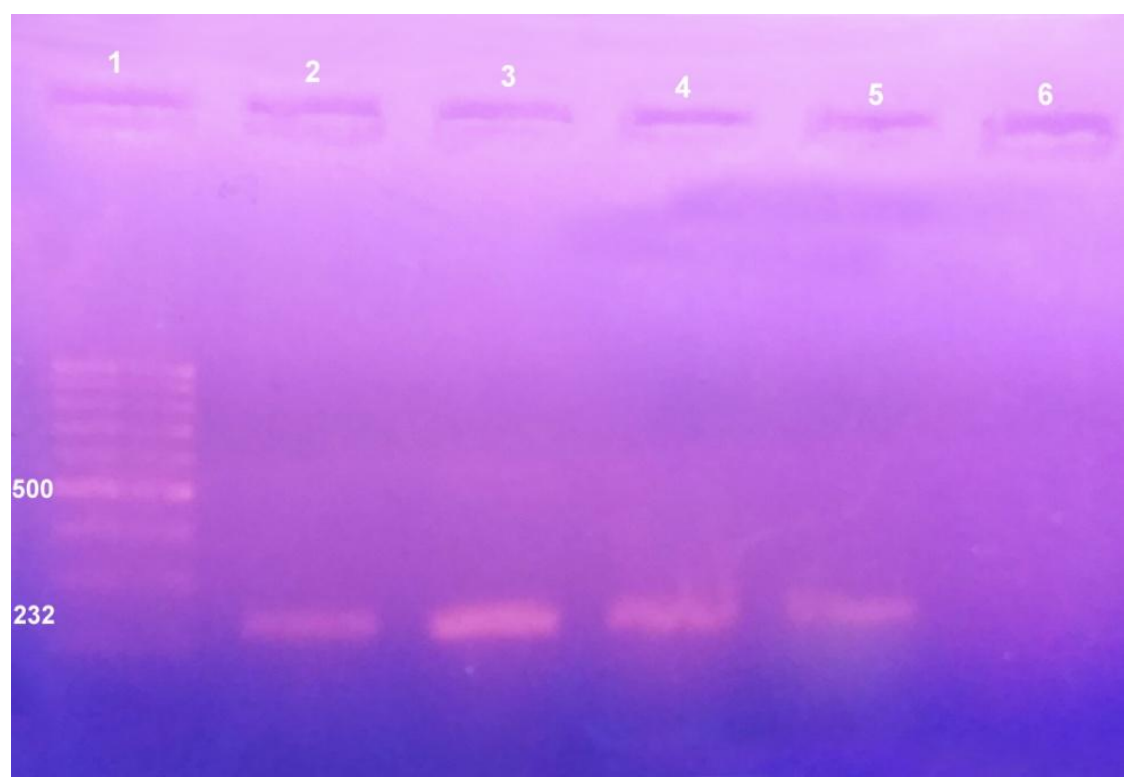

\section{Confirmation by PCR}

Out of the 40 isolates confirmed positive by biochemical tests 26 isolates were found positive by genus specific PCR. PCR gave an amplification of 232 base pairs (Fig. 6) when observed under U.V in gel doc which confirmed the E. coli.

Similar study was done by (Rekha et al., 2006) and they confirmed E. coli isolates by conducting the genus specific PCR targeting Mal B promoter gene (585 bp).

Sabat et al., (1999) conducted genus specific PCR for $E$. coli isolates targeting $16 \mathrm{~S}$ r RNA gene of 544 bp. Nguyen et al., (2016) confirmed the E.coli isolates by genus specific PCR targeting 16S r RNA gene of 654bp.

Out of 100 samples processed, 40 suspected E.coli isolates were identified on the basis of cultural characteristics and biochemical tests and out of 40 isolates, 26 were identified through genus specific PCR.

\section{References}

Ali MY, Rahman MT, Islam MA, Choudhury KA and Rahman MA. 1998. Characteristics of E.coli isolates of human and animal origin. Progressive Agriculturist. 9: 221-224

Beutin L, Geier D, Steinruck H, Zimmermann S and Scheutz F (1993). Prevalence and some properties of verotoxin (Shiga like toxin) producing Escherichia coli in seven different species of healthy domestic animals. Journal of Clinical Microbiology, 31: 2483-2488.

Buxton A and Fraser G (1977). Animal Microbiology. Vol. 1. Blackwell Scientific Publications, Oxford, London, Edinburg. Melbourne pp: 103115.

Dho-Moulin M and Fairbrother J M 1999. Avian pathogenic Escherichia coli (APEC). Veterinary research,30(2-3) pp: 299-316.

Griffin P M and Tauxe R V. 1991. The epidemiology of infections caused by Escherichia coliO157: H7, other 
enterohemorrhagic $E$. coli and the associated hemolytic uremic syndrome. Epidemiological Reviews 13(1): 60-98.

Kang HY, Jeong YS, Oh JY, Tae SH, Choi CH, Moon DC, Lee WK, Lee YC, Seol SY, Cho DT and Lee JC. 2005. Characterization of antimicrobial resistance and class 1 integrons found in Escherichia coli isolates from humans and animals in Korea. Journal of Antimicrobial Chemotherapy 55: 63944.

Kaper, J. B. (2005). Pathogenic Escherichia coli. Int. J. Med. Microbiol. 295, 355356.

Nguyen T T, Van Giau V and Vo T K. 2016. Multiplex PCR for simultaneous identification of E. coli O157: H7, Salmonella spp. and L. monocytogenes in food. 3 Biotech 6(2): p. 205.

Rekha R, Rizvi M A, Jaishree P 2006. Designing and validation of genusspecific primers for human gut flora study. Electronic Journal of Biotechnology.
Riffon R, Sayasith H, Khalil H, Dubereuil P, Dorlet M and Legace J. 2001. Development of a rapid and sensitive test for identification of major pathogens in bovine mastitis by PCR. Journal of Clinical Microbiology 39: 2584-89

Sabat G, Rose P, Hickey W J and Harkin J M. 2000. Selective and sensitive method for PCR amplification of Escherichia coli 16S rRNA genes in soil. Applied Environmental Microbiology 66(2): pp. 844-849.

Vicente HIG, Amaral LA and Cerqueira AMF. 2005. Shigatoxigenic Escherichia coli serogroup O157, O111 and O113 in feces, water and milk samples from dairy farms. Brazilian Journal of Microbiology 36 (3): 217-22.

Yu AC, Loo JF, Yu S, Kong SK, Chan TF (January 2014). "Monitoring bacterial growth using tunable resistive pulse sensing with a pore-based technique". Applied Microbiology and Biotechnology 98 (2): 855-62.

\section{How to cite this article:}

Kumar, K., N.S. Sharma, Paviter Kaur and Arora, A.K. 2019. Detection of E. coli from Sheep and Goat Faecal Samples and Identification by Conventional and Molecular Assay. Int.J.Curr.Microbiol.App.Sci. 8(08): 1074-1080. doi: https://doi.org/10.20546/ijcmas.2019.808.125 